\title{
Johan Fischer - Proper Islamic Consumption: Shopping Among the Malays in Modern Malaysia
}

(Copenhagen: University of Copenhagen, Nordic Institute of Asian Studies, Monograph Series No. 113, 2008), xix+258 pp. ISBN: 978-87-7694-032-4. RM96

Karim D. Crow International Institute of Advanced Islamic Studies (IAIS) Malaysia

This is an excellent study both in substance and in conceptual refinement, opening up important perspectives on the particular mode of 'Islamic modernity' being achieved in Malaysia, and the dynamics of implanting globalised capitalist values within a major Muslim society. From 2001, Fischer did anthropological fieldwork into consumption patterns among Malay middle-class families at Taman Tun Dr Ismail (popularly known as 'TTDI'), a major township in the western part of Kuala Lumpur. The book gives a refined presentation of research on consumption concerning issues of class, market relations and Islamic practice and identity, relating these to IslamState relations in contemporary Malaysia. It could produce discomfort among many Muslims who might not appreciate or comprehend the portrait of Malaysian society reflected in the mirror of academic anthropology. Others with greater perception may experience the peculiar shock of self-recognition - similar to the experience of hearing one's own recorded voice for the very first time - when they read of "middle-class Malays shopping for the state".

The manner and direction in which growing Muslim middle-classes embrace consumerist attitudes and priorities, blending these with key aspects of their own Islamic practice and identity, is one of the great unfolding realities of contemporary Islamic societies. Malaysia provides an instructive example of the role state-sponsored consumerism plays in the 'nationalisation' of Islam within the state and Islam's role as "both an agent and product of globalisation" ( $\mathrm{p}$. xii). Capitalism is adjusting to the new requirements of the growing number of middle-class Muslim Malays while the Islamic market expands rapidly. Serious studies on how consumerism and modern religious consumption in Muslim societies is managed and exploited by societal elites or the state only began to appear over the past decade. Fischer makes a valuable contribution toward understanding what the rise of the consumerist middle-class in civil society portends for emergent modes of modernity in Muslim majority nations. He demonstrates a very good grasp of theoretical issues relating to mass consumption and the 'marketisation' of societies; indeed his bibliography is quite helpful in this regard.

The main thesis of this work is stated by Fischer in the social-science jargon of contemporary social anthropology: 
The nationalisation of Islam and halalisation may be all about creating, fixing and maintaining the religious as a material base, the thingness in enjoyment [...]. The emergence of an ontology of Islamic consumption has infused discursive Islam in Malaysia with an immensely powerful ability to syncretise politics, state, authority and morality. In spite of state nationalist insistence on exorcising the excessively magical, deviationist, ritualistic and adat, these repressions seemingly reappear in the commodity form as fetishes and adornments indispensable to modern forms of state power on the one hand, and individual claims of piety on the other. For purist Malays, halalisation has caused a deep concern with halalised piety. [...] Middle-class Malays work hard to demonstrate how the particularities of their visions are compatible with religious capitalism and modernity. (pp. 232 and 236)

He employs key anthropological notions of 'ritualisation', 'repression', 'fetish' and 'performance of identity', while introducing fresh concepts - "halalised piety" or "ontology of consumption" meaning our way of being consumers or the way the world is viewed and treated for consumption. Fischer also states:

I have tried to show how Islamic practice in Malaysia is undergoing processes of ritualized domestication. This domestication can be seen as a response to or an effect of the wider nationalization of Islam as a hegemonic state project. Growing authoritarianism from the 1970's onwards has produced a crisis of not only authority, but also authenticity for the Malaysian state and UMNO in particular. This crisis has taken on new forms in the era of an emergent ontology of consumption in the Malay middle class. Shopping for the state and patriotic consumption naturally come to mind as forms of re-ritualisation that work as the performance of Malay identities through proper Islamic consumption. [...] This allegiance to the state is preconditioned on trust in its capability to certify and authenticate proper Islamic consumption. (p. 221)

The most significant portion of this study centres on state controlled halalisation as the hallmark of suburban public consumerism moulding many aspects of Malay Muslim behaviour. This actually forms the core of his book (chaps. 3-6, pp. 74-203), and focuses on the implications of urban growth and the 'domestication' of Islamic consumerism. "Focusing on the intimate space of Malay nuclear families in their houses in the suburb puts an emphasis on how urban space and its transformations, and even the nation, is produced and understood in contemporary Malaysia" (p. 13). The impulse for promoting an Islamic vision of haläl authenticity and prosperity derived from the revivalist dakwah commune Darul Arqam originally located in the Sungai Pencala reserve next to the TTDI area. From its establishment in 1971 until the Malaysian National Fatwa Council banned this 'deviant' organisation in 1994, this middle-class commune successfully produced and marketed a wide range of halāl food products and other goods including toothpaste and medication, traded throughout peninsular Malaysia. 
The Arqam group sought full independence from any kind of non-Muslim (read: ethnic Chinese) control, and "successfully promoted this vision of communal selfsufficiency" (p. 3). Fischer observes that the group's alleged Mahdist 'deviationism' and sectarian secrecy became viewed as "an outside other threatening the nation and state nationalist visions of modernity", and became "evoked as the other of the pure and modern national Islam promoted by state nationalism" (p. 4). The authoritarian response of the Malaysian state in banning the commune was matched by an increased move to institutionalise and monopolise the certification of everything halāl in the promotion of religious consumption (pp. 39-44). The various modes of purification are most evident in food consumption, marked by a 'fetishistic' concern with halāl propriety typical of modern Malays.

With regard to the ongoing nationalisation of Islam, Fischer observes (pp. 83-4) that it "[...] is discursively driven in that it encompasses constant competition for the most appropriate Islamic practices [...]. Simultaneously, Malay middle-class groups resisting the pressure for correct conduct and piety are subjected to forms of moral pressure." He further highlights (p. 85): "[...] it is noteworthy that urban Malays are often worried and afraid of being poisoned or sorcerised", and "these fears can easily target food and drink that formally are halal certified, but suspected of being haram and thus impure". Such interiorised attitudes inherent to Malay Muslim identity have a direct bearing upon the reception of current forms of Islamic spiritual practice. For example, ideas about Islamic mysticism and Sufi 'orders' (turuq) display a mixture of admiration for the purity of Sufi tradition, along with suspicion of extremism, excessive secrecy, ritualism, and individualism. Beyond such stereotypical perceptions, Sufism is also being viewed as actively countering material excess, and thereby of concern for the state:

In state imaginings in Malaysia, these secretive and esoteric practices are considered deviationist and unwanted, but they are nevertheless enjoying popularity in the new Malay middle class. The state is fearful of what it sees as uncontrollable, subversive and regressive ritual practices that may displace modern and patriotic national energy. Moreover, piety and moderation are seen as unproductive and un-patriotic. (p. 219)

Fischer demonstrates that nationalisation of Islamic identity and promotion of middle-class consumerism among Malays has been essentially state-driven, serving the self-interests of the political and business classes. The danger remains that prevailing forms of material consumption packaged as indigenous national Islamic identity, will continue to serve the 'marketising' forces of trans-national corporations at the helm of global capitalism. Obsessive concern with purist halāl food consumption, outer dress or ritualistic practice, yields a form of Muslim modernity pervaded by shallow materialist consumerism subject to manipulation by state elites to maintain power and wealth. People thus become outwardly more 'Muslim' yet inwardly less Islamic. 